\title{
EFFECT OF PYRIDINE AND FORMALDEHYDE ON A MACROPHYTE (LEMNA MINOR L.) AND A SLUDGE WORM (TUBIFEX TUBIFEX MÜLLER) IN FRESH WATER MICROCOSMS
}

\author{
B.B. SINGH ${ }^{1}-$ R. CHANDRA. ${ }^{1}$ - - Y.K. SHARMA ${ }^{2}$ \\ ${ }^{1}$ Environmental Microbiology Section, Industrial Toxicology Research Centre, P.O. Box 80, M. \\ G. Marg, Lucknow (U. P) INDIA \\ ${ }^{2}$ Department of Botany, University of Lucknow, Lucknow (U. P) INDIA \\ (phone: +91-0552-2436144 (212); fax: +91-0552-2228227) \\ *Corresponding author \\ e-mail:rc_env@yahoomail.com; ramchandra_env@indiatimes.com \\ (Received $28^{\text {th }}$ November 2006 ; accepted $14^{\text {th }}$ April 2007)
}

\begin{abstract}
Pyridine, a suspected genotoxic and formaldehyde, a potent carcinogen, are present in several industrial wastewater including commercial solvent, resin and pesticide manufacturing industries. The extent of pyridine and formaldehyde toxicity in aquatic organisms is unknown. Therefore, in present study the toxicity of pyridine and formaldehyde were investigated in artificial aquatic ecosystem (microcosm) using two freshwater organisms of different trophic levels i.e. a common duckweed; Lemna minor L. and an oligochaete; Tubifex tubifex Müller. In microcosm, formaldehyde was found to be more toxic to chlorophyll ( 21 days IC50 $=0.08 \pm 0.02 \mathrm{mgL}-1)$, protein ( 21 days IC50 $=0.15 \pm 0.02 \mathrm{mgL}-1)$ and biomass ( 21 days IC50 $=0.18 \pm 0.02 \mathrm{mgL}-1$ ) contents of $\mathrm{L}$. minor than pyridine. In addition, pyridine was found growth supportive to L. minor at concentration of 0.1-0.3 mgL-1. Formaldehyde was found more toxic than pyridine for T. tubifex. Lethal concentrations for formaldehyde were $0.08 \pm 0.004$ (LC10-21 days), $0.2 \pm 0.03$ (LC25-21 days) and $0.39 \pm 0.05 \mathrm{mgL}-1$ (LC50-21 days). For pyridine, lethal concentrations were $0.85 \pm 0.08$ (LC10-21 days), $2.14 \pm 0.2$ (LC25-21days) and 4.27 $\pm 0.3 \mathrm{mgL}-1$ (LC5021days). The concentration and time dependent decrease in growth rate, soluble protein and glycogen content was observed. To overcome the stress situation, high-energy requirement of worms lead to protein and glycogen catabolism. The results of present study might be an important consideration while assessing the hazards of materials to aquatic organisms or when deriving water quality criteria for aquatic organisms.
\end{abstract}

Keywords. Lemna minor L.; Tubifex tubifex Müller; formaldehyde; pyridine; toxicity; microcosms

\section{Introduction}

Increasing industrialization and continuous production of new chemicals has necessitated the advancement of methods for monitoring and treatment to evaluate their damaging effect on the environment. Low acute toxicities are detected in effluents that are discharged from efficient secondary treatment plants [15]. However, such effluents can still include harmful substances that can cause long-term effects by being, for example, genotoxic, hormonally active or bio-accumulative. Many of these substances appear at low concentrations and are of unknown chemical character, which not only makes their chemical analysis time consuming but also requires high tech methods for analysis [35]. For these reasons the use of eco-toxicity tests in effluent monitoring would be useful. In the field of environmental risk assessment, the microcosm is a valuable tool that can be used for evaluation of pure substances as well as whole effluent toxicity (WET) in laboratory. Although smaller and less complex than real 
world freshwater ecosystems, microcosms provide an opportunity to perform ecosystem level research in replicate tests systems under conditions that are manageable in terms of costs and logistics [13].

Pyridine, a $N$-heterocyclic compound, is widely used as solvent in dyes, explosives, pharmaceuticals, pesticides and agro based industries [21]. Pyridine is found in wastewater from these industries that cause human health hazards [44]. Formaldehyde is found in wastewater from resin manufacturers [20] and petrochemical plants [39]. Formaldehyde is also used as an active ingredient in preservatives and disinfectants. Its disposal after use may impair sewage treatment plant performance due to its antimicrobial effects. The demonstration of its carcinogenicity in laboratory animals led to a heightened concern that formaldehyde may present a similar carcinogenic risk to humans [42].

The extent of pyridine and formaldehyde toxicity in aquatic organisms is not well documented. Thus, our purpose of investigation was to evaluate the toxicity of pyridine and formaldehyde to aquatic organisms. We chose two aquatic test models of two different trophic levels, Lemna minor L., a higher plant, and a bottom dweller sludgeworm, Tubifex tubifex Müller.

Common duckweed, Lemna minor L. (Lemnaceae) is a worldwide species and is available throughout the year for use in ecotoxicological research. In addition, the smaller size, simple structure, asexual reproduction and short generation time makes this plant a very suitable candidate for laboratory testing [2, 31]. Parameters, such as total chlorophyll, total protein and biomass, used in the toxicity assays were examined. Tubifex tubifex Müller is a small freshwater endobenthic oligochaete worm that lives in the shallows of freshwater ponds, lakes and marshes containing decomposing organic materials. Because of its wide distribution and culture ease T. tubifex have been proposed as a test organism for ecotoxicological studies [12, 30]. Parameters, such as lethal concentrations $\left(\mathrm{LC}_{10}, \mathrm{LC}_{25}\right.$ and $\left.\mathrm{LC}_{50}\right)$, growth rate, total protein and glycogen content were studied to determine the toxicity impact of pyridine and formaldehyde.

\section{Materials and methods}

\section{Sediment collection and characterization}

Samples were collected from ITRC (Gheru campus), Lucknow $\left(26^{0} 55^{\prime} \mathrm{N} ; 80^{\circ} 59^{\prime} \mathrm{E}\right)$, India on November 2, 2004. General characteristics (sediment particles size, total organic carbon, bulk density, mineral density, water content and porosity) of soil sample were characterized by standard methods [4]. Each bulk sample was homogenized and sieved through a $1 \mathrm{~mm}$ mesh to remove debris of plants and microfauna. Dechlorinated tap water (Table 1.) was added to the bulk of soil samples. The soil slurries obtained were used to prepare the microcosm.

\section{Chemicals}

All chemicals used were of analytical grade and purchased from Sigma-Aldrich, Banglore, India. Manufacturers provided 980 and $1080 \mathrm{mgmL}^{-1}$ strength of pyridine and formaldehyde, respectively. Ten milliliter of pyridine and formaldehyde dissolved in 980 and $1080 \mathrm{~mL}$ distilled water provided strength of $10 \mathrm{mgL}^{-1}$ used as stock solution. Zero, 3, 6, 9, 12, 15, 18, 21, 24 and $27 \mathrm{~mL}$ of stock solution was dissolved in $300 \mathrm{~mL}$ 
soil slurry for strength of $0.0,0.1,0.2,0.3,0.4,0.5,0.6,0.7,0.8$ and $0.9 \mathrm{mgL}^{-1}$ pyridine and formaldehyde.

Table 1. Physico-chemical characteristics of soil and dilution water (tap water)

\begin{tabular}{|c|c|c|c|c|}
\hline \multicolumn{3}{|c|}{$\begin{array}{c}\text { Sediment particles size fraction (\%) and other } \\
\text { characteristics }\end{array}$} & \multicolumn{2}{|c|}{ Dilution water $\left(\mathrm{mgL}^{-1}\right)$} \\
\hline \multirow[t]{7}{*}{ Particles size } & $<15 \mu \mathrm{m}$ & $46.4 \pm 3$ & Potassium & $4.10 \pm 0.06$ \\
\hline & $15-30 \mu \mathrm{m}$ & $27.7 \pm 2$ & Sodium & $35.25 \pm 0.7$ \\
\hline & $30-63 \mu \mathrm{m}$ & $20.0 \pm 0.8$ & Sulphate & $8.55 \pm 0.08$ \\
\hline & $63-125 \mu \mathrm{m}$ & $4.4 \pm 0.07$ & Chloride & $5.0 \pm 0.08$ \\
\hline & $125-250 \mu \mathrm{m}$ & $1.4 \pm 0.02$ & Ammonium & $0.35 \pm 0.004$ \\
\hline & $250-500 \mu \mathrm{m}$ & $0.1 \pm 0.003$ & Total Solids & $350 \pm 31$ \\
\hline & $>500 \mu \mathrm{m}$ & - & Total Dissolved Solids & $325 \pm 23$ \\
\hline \multicolumn{2}{|c|}{ Organic carbon } & $16.5 \pm 0.07$ & Total Suspended Solids & $25 \pm 1$ \\
\hline \multicolumn{2}{|c|}{ Bulk density $\left(\mathrm{gcm}^{-3}\right)$} & $0.08 \pm 0.004$ & $\mathrm{pH}$ & $8.27 \pm 0.3$ \\
\hline \multicolumn{2}{|c|}{ Mineral density ( $\mathrm{gcm}-3)$} & $0.03 \pm 0.001$ & Dissolved Oxygen & $1.10 \pm 0.05$ \\
\hline \multicolumn{2}{|l|}{ Water content } & $90.2 \pm 4$ & Calcium & $15.25 \pm 0.2$ \\
\hline \multicolumn{2}{|l|}{ Porosity } & $0.74 \pm 0.04$ & Total Organic Contents & $0.75 \pm 0.04$ \\
\hline \multicolumn{5}{|l|}{ Heavy metals } \\
\hline \multicolumn{2}{|c|}{$\mathrm{Cd}, \mathrm{Ni} \mathrm{Pb}, \mathrm{Cr}, \mathrm{Zn}$ and $\mathrm{Cu}$} & ND* & $\mathrm{Cd}, \mathrm{Ni} \mathrm{Pb}, \mathrm{Cr}, \mathrm{Zn}$ and $\mathrm{Cu}$ & ND \\
\hline \multicolumn{2}{|c|}{$\mathrm{Fe}$} & $0.4 \pm 0.02$ & $\mathrm{Fe}$ & $0.2 \pm 0.04$ \\
\hline
\end{tabular}

\section{Microcosm preparation}

A total of 120 microcosms were prepared for pyridine and formaldehyde. Individual microcosms were prepared in $1 \mathrm{~L}$ polycarbonate Imhoff settling cones, plugged at the bottom with No. 4 silicon rubber stoppers. Each cone was filled with $150 \mathrm{~mL}$ of the soil slurry, the sides were then rinsed down and the final volume in each cone was brought upto $300 \mathrm{~mL}$ with desired quantity of stock pyridine and formaldehyde.

\section{Lemna minor}

The duckweed culture was collected from a local water body. Water sample were taken and analyzed to confirm that the water body was not laden with pollutants like heavy metals $(\mathrm{Cr}, \mathrm{Zn}, \mathrm{Cu}, \mathrm{Cd}, \mathrm{Ni}$ and $\mathrm{Pb}$ ) and organic chemicals (formaldehyde and pyridine, particularly). The stock was maintained in the laboratory in a plastic bucket with a 20 -L capacity, according to the procedure reported by Chandra and Singh [11]. The stock solution of culture media of Lemna minor was prepared following by OECD guidelines [33].

Twenty four hours before the treatment was initiated duckweed samples were selected for the experiment. A spoonful of duckweed from the stock was placed in a small tray containing cold tap water. Hundred experimental specimens having two fronds of approximately equal size per colony were selected from this tray and transferred to a second tray containing only distilled water. Frond numbers were counted manually with the aid of magnifying glass. Change in fronds e.g. chlorosis (yellowing of frond tissue) and necrosis (white dead frond tissue) was visually observed. Total chlorophyll content was determined on a fresh-weight $\left(\mathrm{mgg}^{-1}\right)$ basis according to standard method [43] on a spectrophotometer (GBC Cintra-40, Australia) 
at absorbance of 645 and $663 \mathrm{~nm}$ using a quartz glass cuvette with $1 \mathrm{~cm}$ thickness. Protein content $\left(\mathrm{mgg}^{-1}\right)$ was spectrophotometrically determined by bicinchoninic acid (BCA) method [10] at absorbance of $562 \mathrm{~nm}$. Biomass was determined by the dry weight method [2] in $\mathrm{mgg}^{-1}$. For convenience, all data in $\mathrm{mgg}^{-1}$ were converted in $\%$. Data were statistically analyzed by an overall one-way analysis of variance (ANOVA) and when differences observed were significant, the mean were compared by TukeyKramer Multiple Comparison Test. IC $_{50}$ (concentration of compound to cause $50 \%$ reduction of biological processes) values were graphically estimated.

\section{Tubifex tubifex}

Tubifex tubifex worms were obtained from a local fish food supplier. The worms were reared at low density (100- 250 individuals) in a 2-L aquarium containing natural sediment and tap water (Table 1.) To avoid accumulation of ammonia, the water was replaced weekly and the worms fed with spinach once a week. The aquarium was placed in a growth chamber in which temperature was $21 \pm 1^{0} \mathrm{C}$ and the lighting was $12 \mathrm{~h}$ dim light/ $12 \mathrm{~h}$ darkness. For luxurious growth, dissolved oxygen (DO) was maintained at $60 \%$ saturation in static cultures [35]. We maintained DO levels by replacing culture water in every 7 days, adding fresh dechlorinated tap water to accommodate evaporation, generous aeration and regulating food. The worms were held for 6 months before experiment. The worms were removed from the sediment $24 \mathrm{~h}$ before use and stored in petri dishes on damp filter paper (in the dark at $14 \pm 1^{\circ} \mathrm{C}$ ) to void gut contents. The selection criteria were equal size and color of body.

Tests were conducted to determine the lethal concentrations $\left(\mathrm{LC}_{10}, \mathrm{LC}_{25}\right.$ and $\left.\mathrm{LC}_{50}\right)$ of pyridine and formaldehyde for worms under laboratory conditions. Fifty worms were introduced in to each microcosm and placed into an incubation chamber $\left(21 \pm 1^{\circ} \mathrm{C}\right.$, and 12:12 $\mathrm{h}$ photoperiod). Three replicates without test compounds were used as control. After 7, 14 and 21 days, dead worms were counted and $\mathrm{LC}_{10}, \mathrm{LC}_{25}$ and $\mathrm{LC}_{50}$ values were determined graphically according to Ammon [1]. LC values from three experiments were averaged and mean \pm standard deviations are presented.

After 7, 14 and 21 days of exposure the weight of T. tubifex was compared to that of control untreated worms. The growth rates were determined using the equation of Martin [26].

Relative growth rate $=\ln W t /$ Wo $\times 100$

Where, Wo is the weight at the beginning of incubation and $W t$ is the weight after $t$ days of exposure.

Total protein content of the worms was determined by dye-binding method [5] using bovine serum albumin as a standard. Glycogen content was determined using the method described by Carol et al. [9]. Glycogen was separated from soluble sugar by precipitation in the presence of methanol. After centrifugation (15 min, 3,000 rpm), precipitates were used for glycogen quantification with anthron reagent according to the sulfuric acid method of Kemp \& Heijningen [22]. Calibration was performed using standard of glucose ranging 0 to $200 \mu \mathrm{g}$ which received the same treatment as the samples. 


\section{Extraction and quantification of pyridine and formaldehyde}

Water, in which L. minor and T. tubifex were incubated, was analyzed directly for pyridine with High Performance Liquid Chromatography (HPLC; Metrohm, Micro Devices, Switzerland) without pre-concentration. Whereas, for worms, $2 \mathrm{gm}$ of sample from each microcosms, was homogenized in $10 \mathrm{~mL}$ of hexane using a glass homogenizer immersed in ice. The homogenate was mechanically shaken for $120 \mathrm{~min}$, filtered and then washed twice with $5 \mathrm{~mL}$ of hexane. The combined extract, were then centrifuged at 10,000 rpm for $5 \mathrm{~min}$ at $4^{0} \mathrm{C}$ and quantitatively transferred to a volumetric flask. The final volume was recorded and the hexane extract stored at $4^{0} \mathrm{C}$. The total extract was evaporated to dryness under a nitrogen stream, the residue was dissolved in $1 \mathrm{~mL}$ of acetonitrile and injected into the HPLC [29]. Formaldehyde content in worms, sediment and water was analyzed by spectrophotometrically by formation of diacetyldihydrolutidine (DDL) [32].

\section{Results}

\section{Duckweed toxicity test}

Initial fronds number was 100 for each microcosms treated with different concentrations of formaldehyde and pyridine $\left(0-0.9 \mathrm{mgL}^{-1}\right)$. In formaldehyde treated microcosms, concentrations $>0.3 \mathrm{mgL}^{-1}$ were found highly growth inhibitor in terms of total chlorophyll, total protein and biomass (Table 2.). Even at very low concentration $\left(0.1 \mathrm{mgL}^{-1}\right)$ chlorosis started after 7 days and $20 \%$ chlorosis was recorded at 9 days. Whereas, at $0.3 \mathrm{mgL}^{-1}$ formaldehyde, $50 \%$ chlorosis was recorded after 12-days exposure. After 18 days, even $0.2 \mathrm{mgL}^{-1}$ formaldehyde showed $100 \%$ necrosis. Interestingly, it was observed that at lower concentrations, pyridine $\left(0.1-0.2 \mathrm{mgL}^{-1}\right)$ was growth supportive to L. minor in terms of total chlorophyll, total protein and biomass (Table 2.).

Table 2. Effect of pyridine and formaldehyde on total chlorophyll, protein and biomass content of L. minor after 21 days exposures, expressed as percent of control

\begin{tabular}{llrrrrr}
\hline Conc. & \multicolumn{2}{c}{ Total chlorophyll } & \multicolumn{2}{c}{ Protein } & \multicolumn{2}{c}{ Biomass } \\
\cline { 2 - 7 }$\left(\mathrm{mgL}^{-1}\right)$ & Formaldehyde & \multicolumn{1}{c}{ Pyridine } & \multicolumn{1}{c}{ Formaldehyde } & Pyridine & \multicolumn{1}{c}{ Formaldehyde } & Pyridine \\
\hline 0.0 & 100.00 & 100.00 & 100.00 & 100.00 & 100.00 & 100.00 \\
0.1 & $35.50^{\mathrm{a}} \pm 0.25$ & $113.13^{\mathrm{a}} \pm 1.25$ & $65.45^{\mathrm{a}} \pm 0.75$ & $120.75^{\mathrm{a}} \pm 0.36$ & $75.35^{\mathrm{a}} \pm 0.85$ & $100.21^{\mathrm{a}} \pm 0.12$ \\
0.2 & $25.75^{\mathrm{a}} \pm 0.15$ & $108.60^{\mathrm{a}} \pm 0.98$ & $35.25^{\mathrm{a}} \pm 0.36$ & $125.07^{\mathrm{a}} \pm 0.45$ & $45.15^{\mathrm{a}} \pm 0.25$ & $140.28^{\mathrm{a}} \pm 0.68$ \\
0.3 & $5.05^{\mathrm{a}} \pm 0.10$ & $90.16^{\mathrm{a}} \pm 1.05$ & $5.25^{\mathrm{a}} \pm 0.05$ & $115.45^{\mathrm{a}} \pm 0.55$ & $10.45^{\mathrm{a}} \pm 0.10$ & $105.10^{\mathrm{a}} \pm 0.10$ \\
0.4 & 0.00 & $55.13^{\mathrm{a}} \pm 0.63$ & $2.15^{\mathrm{a}} \pm 0.03$ & $75.97^{\mathrm{a}} \pm 1.25$ & $5.25^{\mathrm{a}} \pm 0.04$ & $88.65^{\mathrm{a}} \pm 0.65$ \\
0.5 & 0.00 & $45.51^{\mathrm{a}} \pm 0.45$ & 0.00 & $65.25^{\mathrm{a}} \pm 0.88$ & $2.35^{\mathrm{a}} \pm 0.05$ & $75.25^{\mathrm{a}} \pm 0.75$ \\
0.6 & 0.00 & $30.23^{\mathrm{a}} \pm 0.35$ & 0.00 & $45.88^{\mathrm{a}} \pm 0.65$ & 0.00 & $48.35^{\mathrm{a}} \pm 0.55$ \\
0.7 & 0.00 & $5.42^{\mathrm{a}} \pm 0.02$ & 0.00 & $12.36^{\mathrm{a}} \pm 0.54$ & 0.00 & $5.65^{\mathrm{a}} \pm 0.07$ \\
0.8 & 0.00 & 0.00 & 0.00 & $9.25^{\mathrm{a}} \pm 0.08$ & 0.00 & $2.88^{\mathrm{a}} \pm 0.03$ \\
0.9 & 0.00 & 0.00 & 0.00 & $5.45^{\mathrm{a}} \pm 0.06$ & 0.00 & $2.45^{\mathrm{a}} \pm 0.04$ \\
\hline
\end{tabular}

Data presented are means $(\mathrm{n}=3) \pm$ standard deviation; ${ }^{a}$ highly significant; ANOVA $\mathrm{p}<0.001,{ }^{\mathrm{d}}$ non significant; ANOVA $\mathrm{p}>0.05$.

During 6 days of pyridine exposure, no chlorosis as well as necrosis was observed at any concentration. After 9 days of pyridine exposure, chlorosis and necrosis were 
observed at $0.4 \mathrm{mgL}^{-1}$ and $0.5 \mathrm{mgL}^{-1}$, respectively. At the end of experiment (21 days), higher concentrations of pyridine $\left(>0.4 \mathrm{mgL}^{-1}\right)$ showed higher chlorosis $(80-100 \%)$ as well as necrosis (70-100\%) as compared to control. According to the data (Table 2.) the 21 day $\mathrm{IC}_{50}$ values of pyridine and formaldehyde for total chlorophyll, total protein and biomass are presented in Table 3.

L. minor exposed to pyridine showed an $\mathrm{IC}_{50}$ value $0.45 \pm 0.04$ for total chlorophyll content, which was 5.8 times of formaldehyde $\left(\mathrm{IC}_{50} 0.08 \pm 0.002\right)$. In terms of protein content, $L$. minor showed an $\mathrm{IC}_{50}$ value of $0.58 \pm 0.03$ for pyridine, which is 3.9 times more than formaldehyde ( $\mathrm{IC}_{50} 0.15 \pm 0.02$ ). While, for biomass $\mathrm{IC}_{50}$ value for pyridine was found 3.3 times more than formaldehyde (Table 3.).

Table 3. $I C_{50}$ values $\left(\mathrm{mgL}^{-1}\right)$ of pyridine and formaldehyde to L. minor after 21 days

\begin{tabular}{lccc}
\hline \multirow{2}{*}{ Compounds } & \multicolumn{3}{c}{ IC $_{\mathbf{5 0}}$ values for $\boldsymbol{L}$. minor } \\
\cline { 2 - 4 } & Chlorophyll & Protein & Biomass \\
\hline Pyridine & $0.45 \pm 0.04$ & $0.58 \pm 0.03$ & $0.59 \pm 0.02$ \\
Formaldehyde & $0.08 \pm 0.002$ & $0.15 \pm 0.02$ & $0.18 \pm 0.02$ \\
\hline
\end{tabular}

\section{Tubificid toxicity test}

\section{Mortality}

For the control group no mortality was observed. In presence of pyridine and formaldehyde, some mortality was recorded and it increased with the pyridine and formaldehyde concentrations. In formaldehyde treated microcosms, 50\% mortality $\left(\mathrm{LC}_{50}\right)$ was recorded at $>0.8 \mathrm{mgL}^{-1}$ concentration with in 7 days. Whereas, in pyridine treated microcosms $\mathrm{LC}$ values $\left(\mathrm{LC}_{10}, \mathrm{LC}_{25}\right.$ and $\left.\mathrm{LC}_{50}\right)$ were recorded higher than formaldehyde (Table 4.)

Table 4. Lethal concentrations $\left(m g L^{-1}\right)$ of pyridine and formaldehyde to T. tubifex after 7,14 and 21 days of exposure.

\begin{tabular}{lllll}
\hline Compounds & & \multicolumn{1}{c}{ 7-days } & 14-days & 21-days \\
\hline \multirow{3}{*}{ Pyridine } & $\mathrm{LC}_{10}$ & $2.66 \pm 0.2$ & $1.25 \pm 0.1$ & $0.85 \pm 0.08$ \\
& $\mathrm{LC}_{25}$ & $6.42 \pm 0.4$ & $3.13 \pm 0.3$ & $2.14 \pm 0.2$ \\
& $\mathrm{LC}_{50}$ & $12.84 \pm 0.2$ & $6.25 \pm 0.4$ & $4.27 \pm 0.3$ \\
Formaldehyde & $\mathrm{LC}_{10}$ & $0.15 \pm 0.01$ & $0.1 \pm 0.01$ & $0.08 \pm 0.004$ \\
& $\mathrm{LC}_{25}$ & $0.36 \pm 0.02$ & $0.24 \pm 0.04$ & $0.2 \pm 0.03$ \\
& $\mathrm{LC}_{50}$ & $0.73 \pm 0.08$ & $0.48 \pm 0.04$ & $0.39 \pm 0.05$ \\
\hline
\end{tabular}

Data presented are means $(\mathrm{n}=3) \pm$ standard deviation

\section{Growth rate}

The growth rate of untreated (control) worms was positive and although it was not significant, it increases from 102 to $155 \%$ from 7 day to the 21 day measurement. In contrast, pyridine and formaldehyde treated worms lost weight, as showed in Fig. 1 \& 2. This decrease of weight was time and concentration dependent. At $0.9 \mathrm{mgL}^{-1}$ concentration of pyridine, the growth rate was reduced to $65 \pm 4 \%, 40 \pm 2 \%$ and $42 \pm 2 \%$ after 7, 14 and 21 days of exposure, respectively. While, at $0.9 \mathrm{mgL}^{-1}$ concentration of 
formaldehyde, the reduction was $80 \pm 5.4,60 \pm 5$ and $62 \pm 4 \%$ in 7,14 and 21 days of exposure, respectively (Fig. $1 \& 2$.).

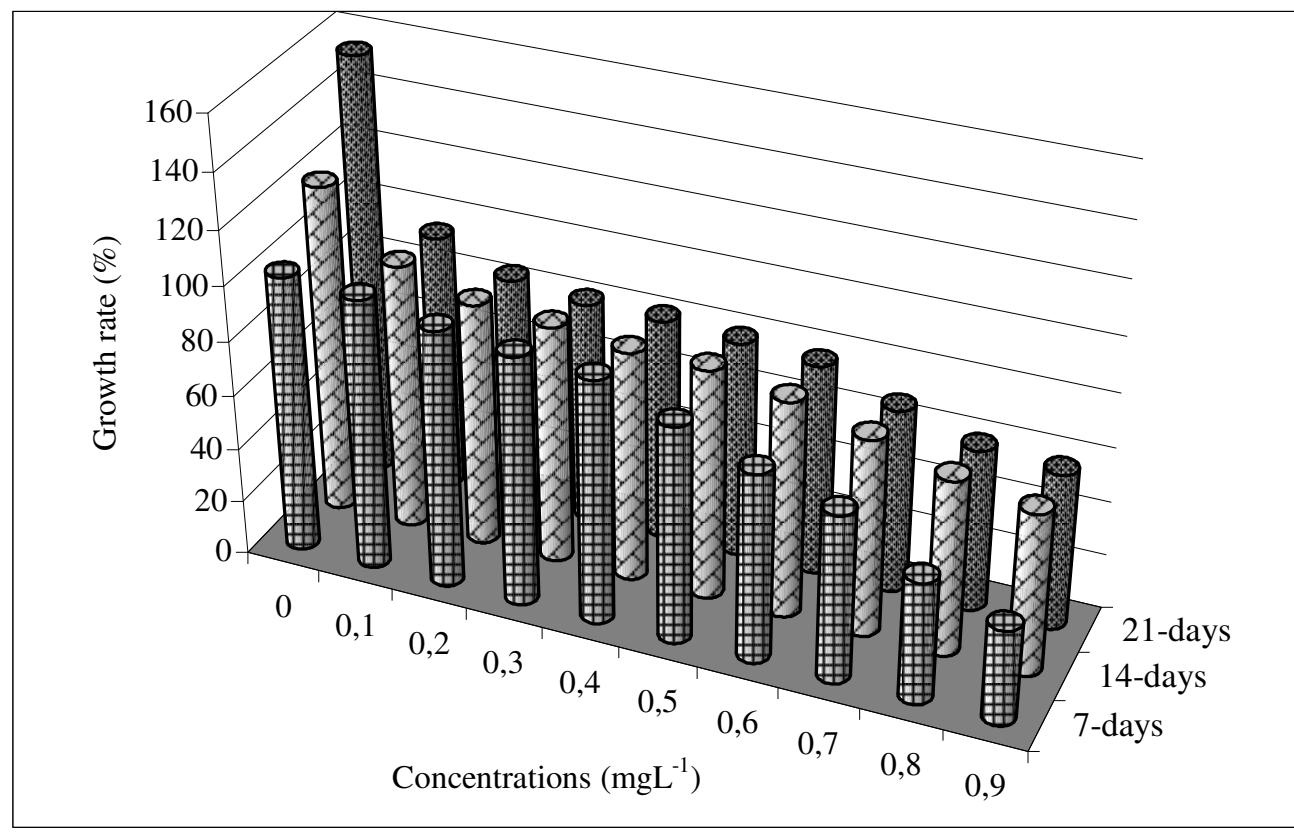

Figure 1. Effect of various pyridine concentrations on the relative growth rate of $T$. tubifex after 7, 14 and 21 days of exposure

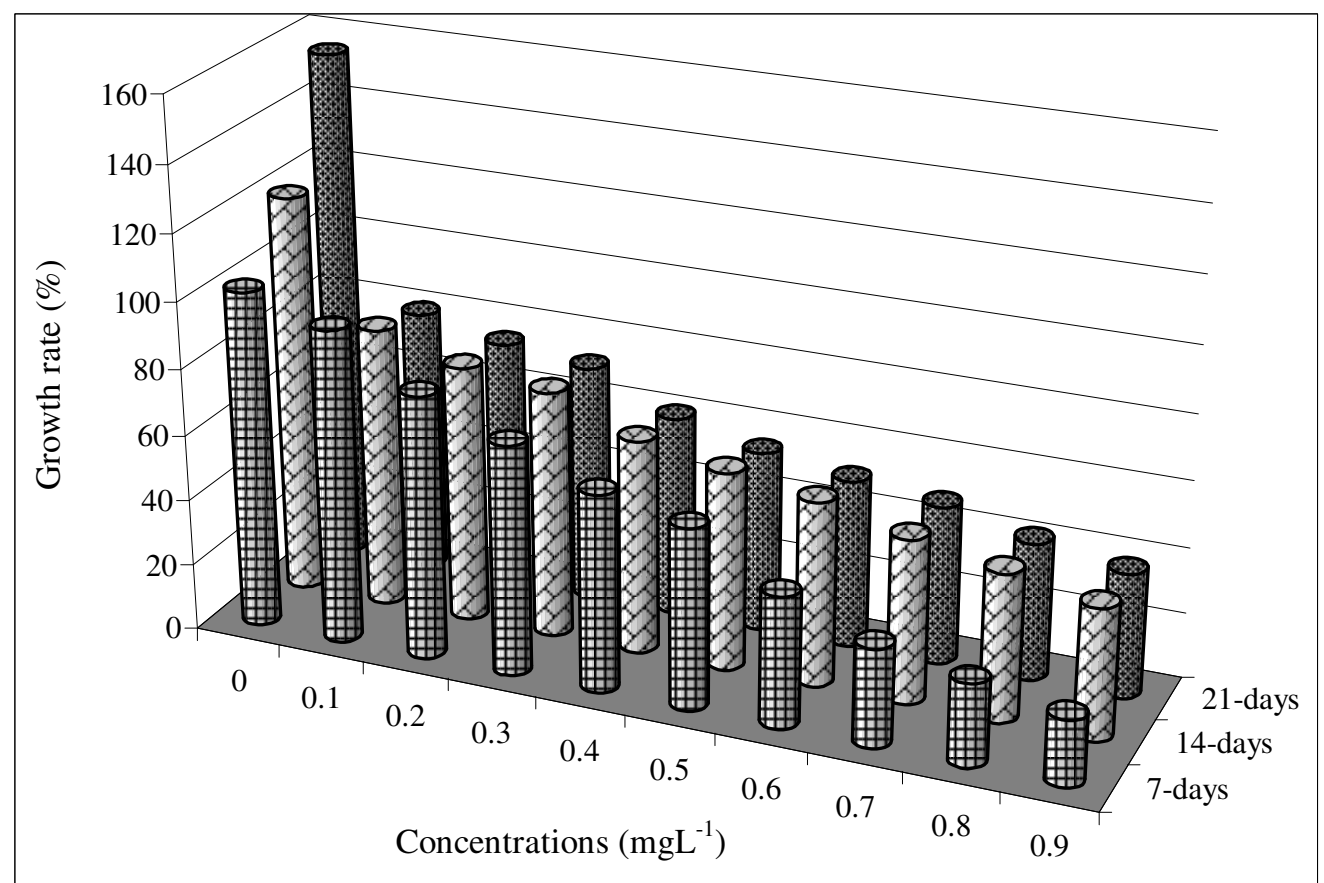

Figure 2. Effect of various formaldehyde concentrations on the relative growth rate of $T$. tubifex after 7, 14 and 21 days of exposure 


\section{Total protein and glycogen content}

In control T. tubifex, the concentration of soluble protein was increased significantly throughout the experiment (1500-2325 $\left.\pm 24 \mu \mathrm{g}-\mathrm{g} \mathrm{FW}^{-1}\right)$. In exposed worms, the decrease of total protein was time and concentration dependent. At higher concentration, pyridine and formaldehyde both significantly reduced $(\mathrm{p}<0.01)$ reduced total protein content of worms (Fig. 3 \& 4.).

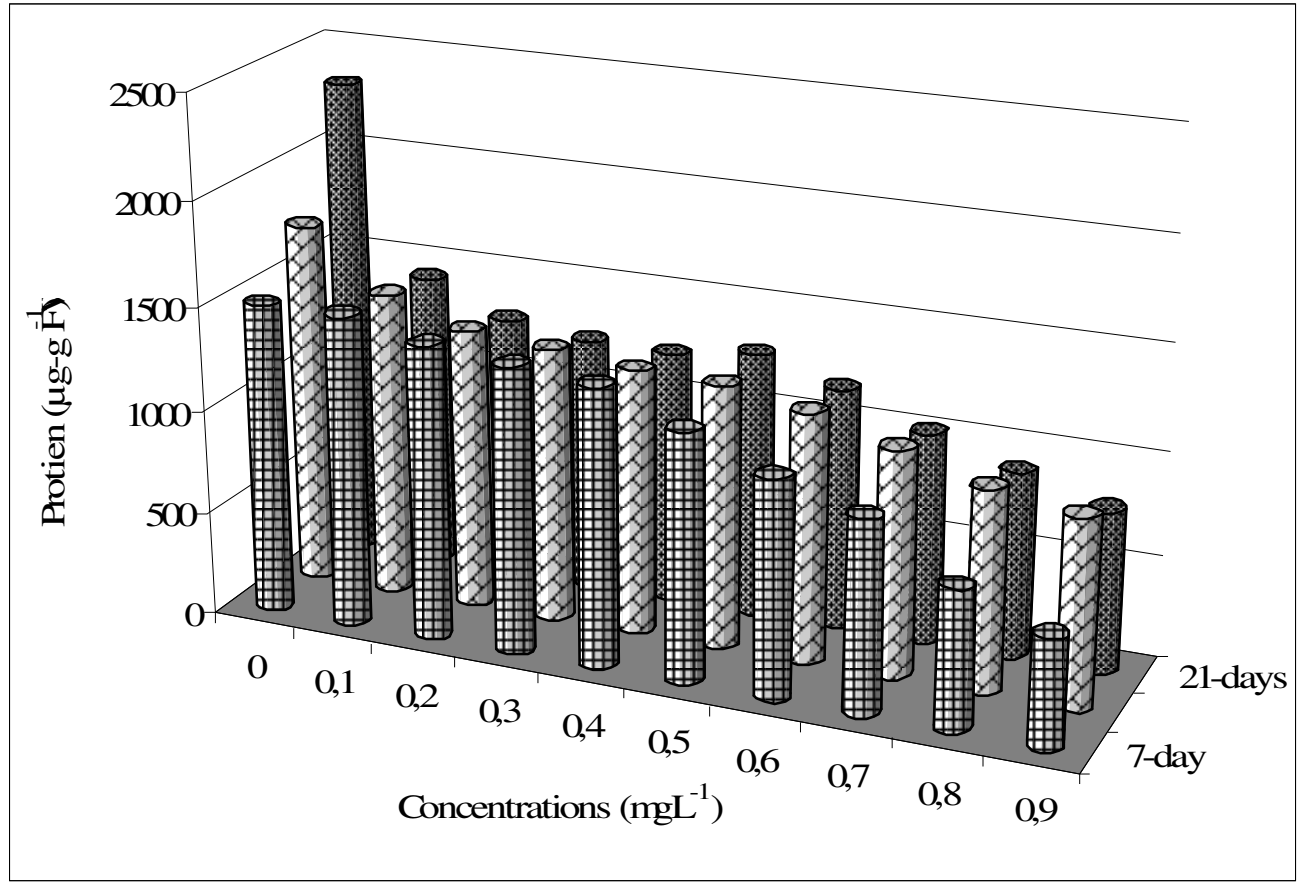

Figure 3. Effect of various pyridine concentrations on total soluble protein concentration of $T$. tubifex after 7, 14 and 21 days of exposure

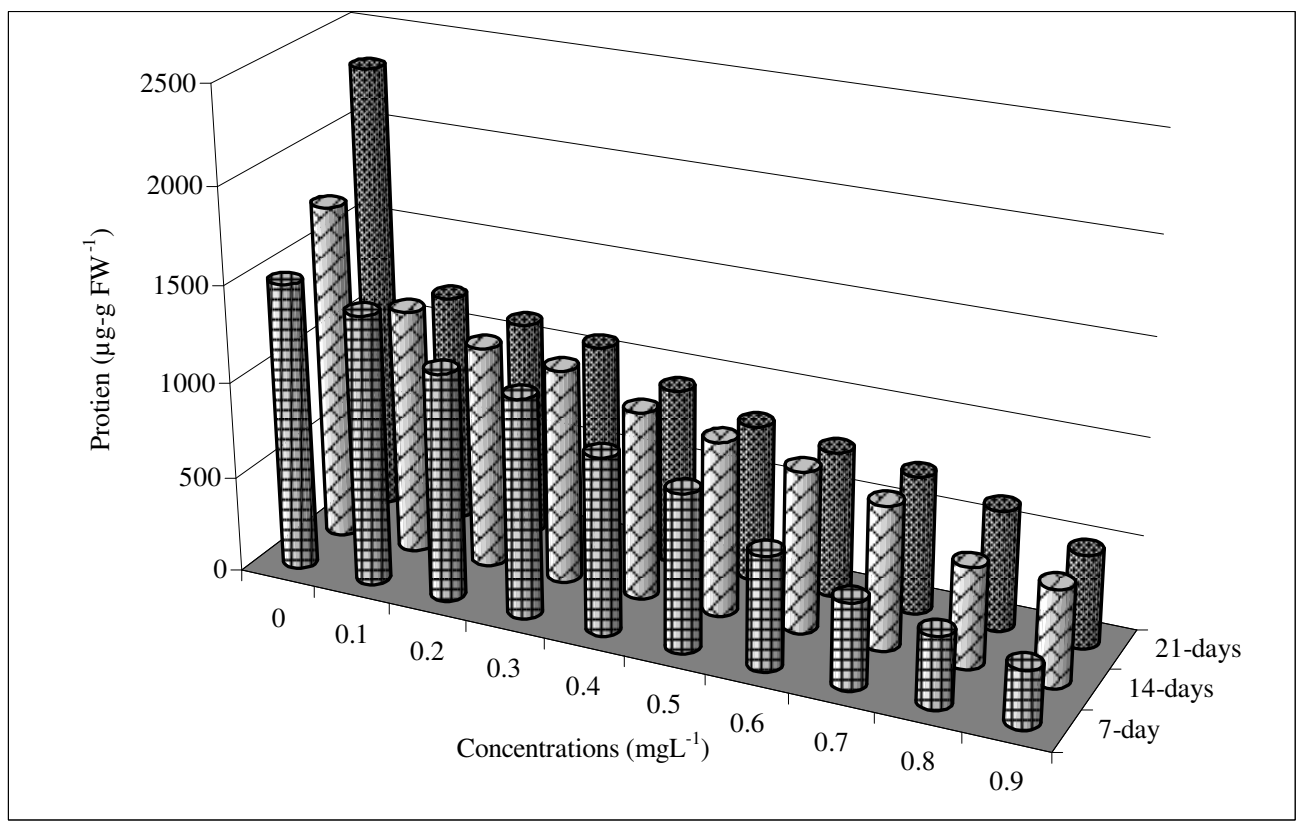

Figure 4. Effect of various formaldehyde concentrations on total soluble proteinconcentration of T. tubifex after 7, 14 and 21 days of exposure 
Similarly to protein, the glycogen level in the treated worms was significantly lower than those in control worms, which was approximately $10.47 \pm 0.4$ to $19.76 \pm 1 \mu \mathrm{g}-\mathrm{g} \mathrm{FW}^{-1}$. This decrease was further concentration and time dependent and reached 34.95 \pm 2.5 , $59.12 \pm 3.2$, and $57.97 \pm 2.5 \%$ after 7,14 and 21 days in $0.9 \mathrm{mgL}^{-1}$ pyridine treated worms. While, in formaldehyde treated worms, this decrease was reached $19.96 \pm 2,36.63 \pm 2.4$ and $37.06 \pm 2.6 \%$ at $0.9 \mathrm{mgL}^{-1}$ concentration (Fig. $5 \& 6$.).

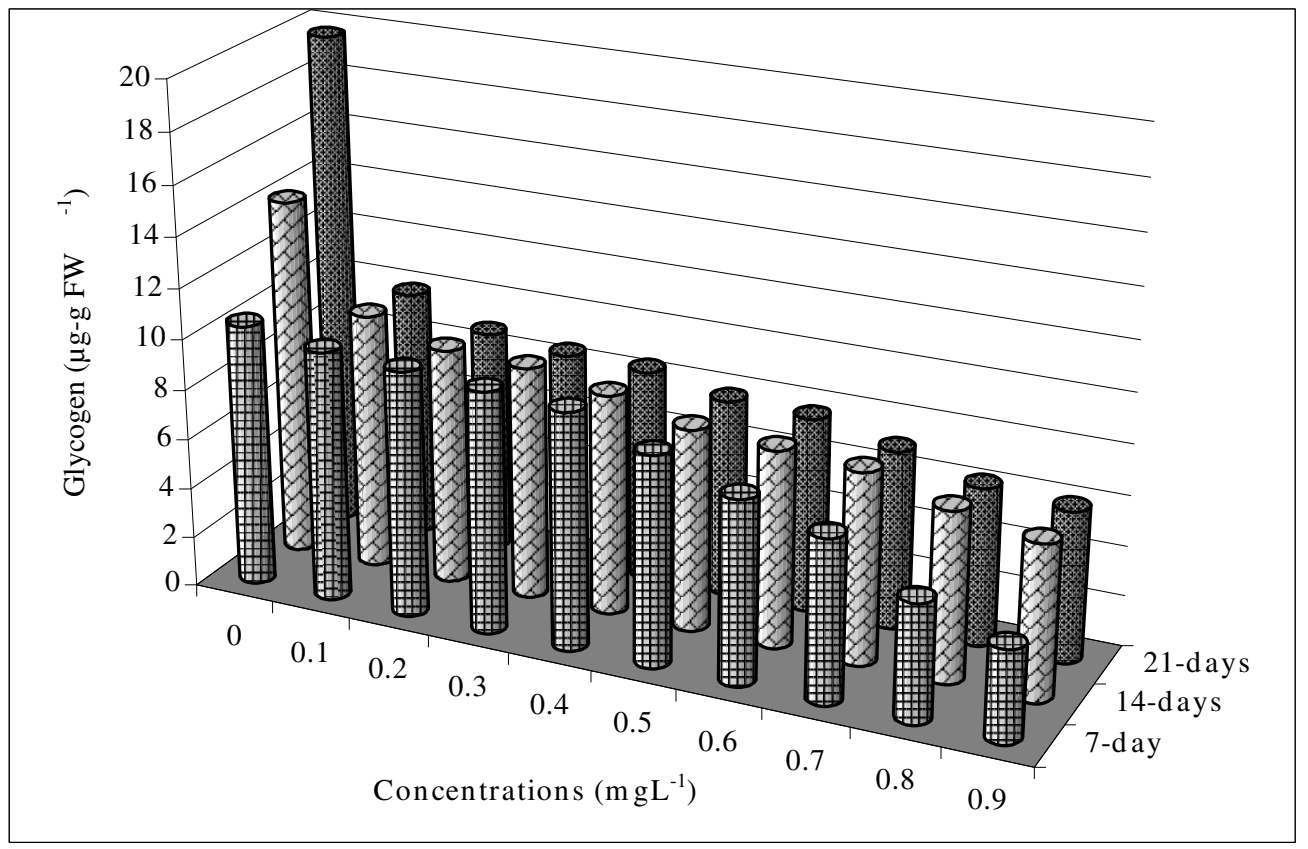

Figure 5. Effect of various pyridine concentrations on glycogen concentration of T. tubifex after 7, 14 and 21 days of exposure

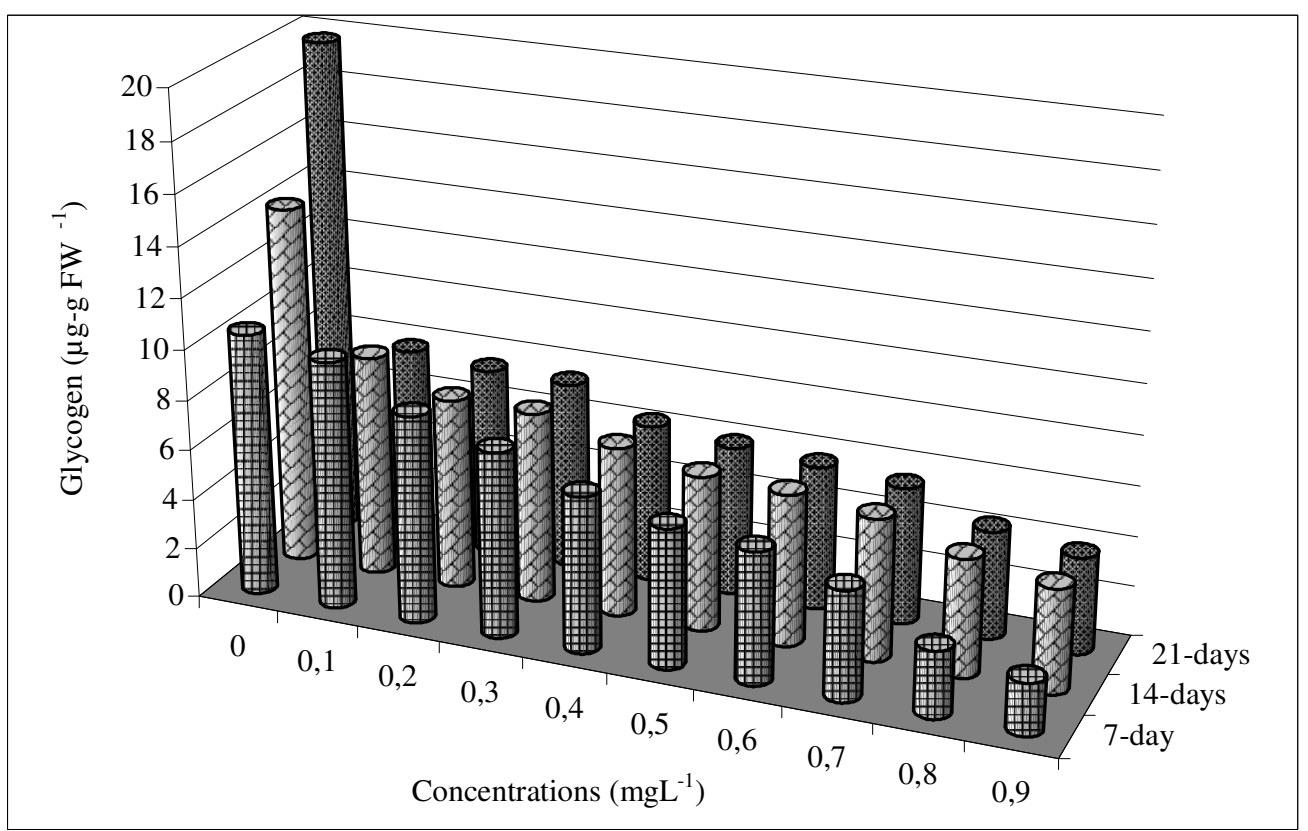

Figure 6. Effect of various formaldehyde concentrations on glycogen concentration of T. tubifex after 7, 14 and 21 days of exposure 


\section{Pyridine and formaldehyde residues}

After 7, 14 and 21 days, residues of pyridine and formaldehyde were detected in all exposed worms and exposure water (Table $4 \& 5$.). In the water, the concentration of both pyridine and formaldehyde was highest after 7 days and decreased thereafter. The relative decrease was more rapid with low initial concentrations of pyridine and formaldehyde. Indeed, after 7 days 80, 90 and $96.66 \%$ and after 21 days 50, 50 and $85 \%$ of the pyridine was left for the $0.1,0.5$ and $0.9 \mathrm{mgL}^{-1}$ initial concentrations, respectively. While, after 7 days 60,84 and $91.11 \%$ and after 21 days 30, 26, 77.77\% of the formaldehyde was left for the $0.1,0.5$ and $0.9 \mathrm{mgL}^{-1}$ initial concentrations, respectively (Table 4.).

Table 5. Residue of pyridine and formaldehyde in exposure water of microcosms $\left(m g L^{-1}\right)$ in which T. tubifex were incubated during 7, 14 and 21 days

\begin{tabular}{|c|c|c|c|c|}
\hline \multirow{2}{*}{\multicolumn{2}{|c|}{ Initial concentration $\left(\mathrm{mgL}^{-1}\right)$}} & \multicolumn{3}{|c|}{ Duration } \\
\hline & & 7-days & 14-days & 21-days \\
\hline \multirow{3}{*}{ Pyridine } & Control & ND* & ND & ND \\
\hline & & & & \\
\hline & 0.1 & $0.08 \pm 0.02^{\mathrm{a}}$ & $0.06 \pm 0.01^{\mathrm{b}}$ & $0.05 \pm 0.02^{c}$ \\
\hline \multirow{6}{*}{ Formaldehyde } & 0.5 & $0.45 \pm 0.04^{\mathrm{d}}$ & $0.35 \pm 0.02^{\mathrm{e}}$ & $0.25 \pm 0.02^{\mathrm{f}}$ \\
\hline & 0.9 & $0.87 \pm 0.15^{\mathrm{g}}$ & $0.82 \pm 0.15^{\mathrm{g}}$ & $0.77 \pm 0.20^{\mathrm{h}}$ \\
\hline & & & & \\
\hline & 0.1 & $0.06 \pm 0.02^{\mathrm{a}}$ & $0.04 \pm 0.01^{\mathrm{b}}$ & $0.03 \pm 0.01^{\mathrm{c}}$ \\
\hline & 0.5 & $0.42 \pm 0.03^{\mathrm{d}}$ & $0.31 \pm 0.05^{\mathrm{e}}$ & $0.13 \pm 0.04^{\mathrm{f}}$ \\
\hline & 0.9 & $0.82 \pm 0.25^{\mathrm{g}}$ & $0.76 \pm 0.20^{\mathrm{h}}$ & $0.70 \pm 0.25^{\mathrm{h}}$ \\
\hline
\end{tabular}

Data presented are means $(n=3) \pm$ standard deviation; *ND- not detected; Figures followed by identical superscript letter are not significantly different

Table 6. Residue of pyridine and formaldehyde in T. tubifex $\left(\mu g-g^{-1} F W\right)$ after 7,14 and 21 days

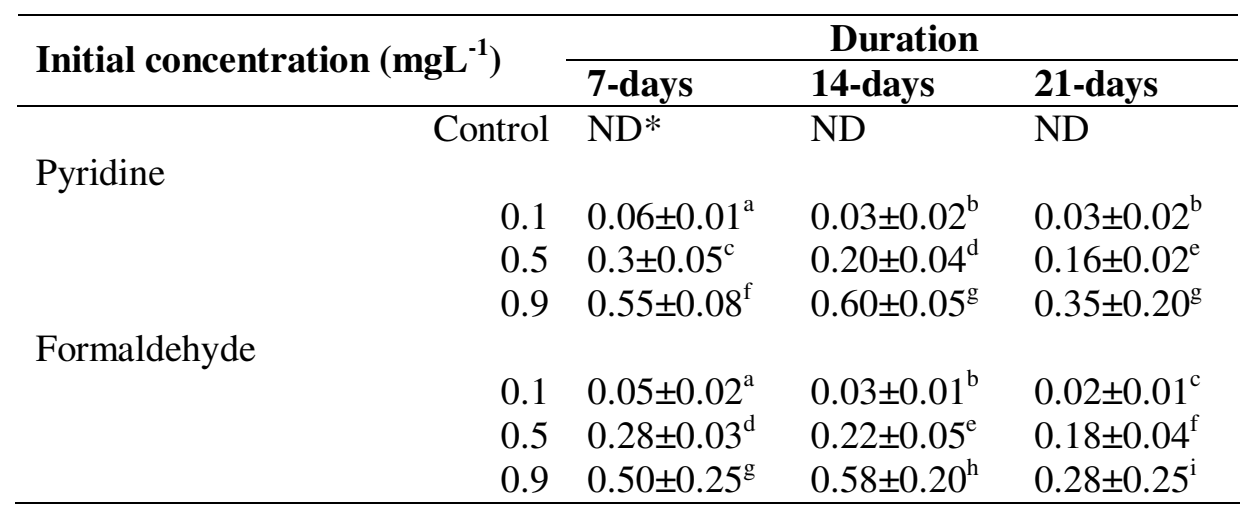

All values are mean $(\mathrm{n}=3) \pm$ standard deviation ; *ND- not detected; Figures followed by identical superscript letter are not significantly different.

In the worms, the concentrations of pyridine reached a maximum of $60-61.11 \%$ after 7 days for all the initial concentrations used and decreased thereafter, representing 30,40 and $66.66 \%$ after 14 days, 30, 32 and $38.88 \%$ after 21 days of exposure of 0.1 , 0.5 and $0.9 \mathrm{mgL}^{-1}$ concentrations, respectively. While, the concentration of formaldehyde was found to be 50, 56 and 55.55\% after 7 days, 30, 44 and 64.44 after 14 
days and 20,36 and $31.11 \%$ after 21 days at $0.1,0.5$ and $0.9 \mathrm{mgL}^{-1}$ concentrations, respectively (Table 5.).

\section{Discussion}

\section{Duckweed toxicity test}

\section{Pyridine toxicity}

Our results suggested that pyridine affects biomass and protein content in the same manner as in the chlorophyll. Due to high water solubility and low octanol-water partition coefficient $\left(K_{o w}\right)(1.04)$ of pyridine, the cells of $L$. minor have an affinity to pyridine [11]. Since, the pyridine containing herbicides (i.e. diaquat and paraquat) specifically exert phytotoxic action on photosystem II; changes in the chlorophyll content can be a reliable indicator of toxicity [27]. At each lower concentrations, pyridine stimulated production of the chlorophyll, protein and biomass content as well. Mayer and Jensen [28] have also reported triazine, an n-heterocyclic ring containing herbicide, induced increase of the algal chlorophyll and biomass in Selenastrum capricornatum. This process may result from homeostasis triggered, as a tolerance mechanism, by the exposure to the herbicides [17]. Responses such as the synthesis of thylakoid components are considered to be a general adaptive response to situations in which the electron transport rate is strongly limited for photosynthesis [3]. An increase in protein content in L. minor at lower concentrations of pyridine could also be related with aforesaid detoxification mechanism. For instance, other solvents and herbicides have been shown to be detoxified by various microalgal species and subsequent binding to a protein [24].

\section{Formaldehyde toxicity}

At lower concentrations, plants inefficiently remove formaldehyde and detoxify or convert it to natural products [19]. The enzyme responsible for formaldehyde detoxification was isolated and characterized as glutathione dependent formaldehyde dehydrogenase forming formic acid. This product is then assimilated into amino acids, sugars and natural products [16]. But at higher concentrations $(>0.1 \%)$, formaldehyde is very toxic to photosynthetic systems, as well as protein and biomass contents of plant. Due to very low $K_{o w}$ value of formaldehyde $(0.35)$ and high water solubility, the cells of L. minor have an affinity for formaldehyde molecules [36]. Once inside the cell formaldehyde inhibits the biological mechanisms i.e. protein synthesis and photosynthesis of plant. But the mode of formaldehyde toxicity in plant is still unknown. In addition, formaldehyde was found approximately three times more toxic than pyridine due to its approximately three times lower $K_{o w}$ value $(0.35)$ than pyridine ( $K_{\text {ow }}$ value 1.04$)$.

\section{Tubifex tubifex toxicity test}

\section{Pyridine and formaldehyde toxicity}

The values of $\operatorname{LC}_{10}\left(2.66 \pm 0.2 \mathrm{mgL}^{-1}\right.$ after 7 days, $1.25 \pm 0.1 \mathrm{mgL}^{-1}$ after 14 days and $0.85 \pm 0.08 \mathrm{mgL}^{-1}$ after 21 days, Table 4.) indicated a low toxicity of pyridine towards $T$. 
tubifex. While, the of $\mathrm{LC}_{10}$ values $\left(0.15 \pm 0.01 \mathrm{mgL}^{-1}\right.$ after 7 days, $0.1 \pm 0.01 \mathrm{mgL}^{-1}$ after 14 days and $0.08 \pm 0.004 \mathrm{mgL}^{-1}$ after 21 days, Table 4.) of formaldehyde indicated a moderately high toxicity towards $T$. tubifex.

The growth rate of untreated worms was positive. In contrast, the treated worms lost weights. Reduction in feeding activity as a strategy to avoid the pyridine containing pesticides was proposed to explain the weight reduction in an isopods [37]. In our case, this possibility may be ruled in and it may be proposed that $T$. tubifex growth rate was reduced because of a higher consummation of the reserves.

The reduction of protein content may be ascribed to a catabolism of protein in response to worm energy demand as suggested for an isopod in response to a pyridine containing pesticides [37]. Several authors have shown that the reduction of worm protein content was one of the primary toxic effects of various pesticides, this decrease of protein content appeared to be an early defense reaction to the pesticides stress in animals. To overcome the stress situation, animal require high energy and this energy may have led to protein catabolism. Furthermore, this decrease in protein content might be due to a mechanical lipoprotein formation, which will be used to repair damaged cells, tissues and organs [37]. Similarly to protein, the depletion of glycogen may be due to direct utilization of this compound for energy generation, as a result of pesticideinduced stress [38]. Glycogen is rapidly catabolised, resulting in an important decrease in this energy reserve.

Major fraction of pyridine and formaldehyde was absorbed through the skin (via mucous) due to its high water solubility and minor fraction was entered via food [37] in $T$. tubifex. Once inside the body of worms, pyridine was eliminated through the skin as free-base and as metabolites [6]. The metabolic fate of pyridine in aquatic organisms is still poorly understood. In formaldehyde treated worms, formaldehyde must be first deposited on the outer surface of the mucous blanket for causing toxicity. Mucous is made-up of water [ $\geq 95 \%$,] mucous glycoprotein [0.5-1\%], free proteins and salts, with other materials in such smaller amount [14]. Before formaldehyde can directly affect the underlining epithelium they must penetrate this superficial layer [41]. Due to their low $K_{o w}$ value formaldehyde binds readily to mucous proteins [18] and polysaccharides [23] thereafter, diffuse through the underlining periciliary fluid and altered the normal functioning of the cell. But, the exact mechanisms and their metabolic fate are still unknown.

\section{Speciation of formaldehyde and pyridine}

In the environment, decrease in the concentration of a compound in water may be due to adsorption, translocation and degradation. In our experiment, adsorption and translocation can be ruled out due to very low octanol-water partition coefficient $\left(K_{o w}\right)$ $[7,40]$ and very low organic content of used sediment (Table 1.). Disappearance of the pyridine and formaldehyde in our case is probably due to biodegradation. The slower decrease with high concentrations of pyridine and formaldehyde may be attributed to a possible toxicity to T. tubifex and microorganisms that may be present in the medium. Decreasing pyridine and formaldehyde availability in the water may not solely be invoked the concentration decrease in the worms, indeed concentration decrease was not as rapid in the water as in the worms (Table $4 \& 5$ ). Furthermore, for the highest initial concentration, the pyridine and formaldehyde concentration in the worms increased from day 7 to 14 and it slightly (although not significantly) decreased thereafter. This slight decrease of pyridine and formaldehyde in worms is a defense 
mechanism of T. tubifex. Continuous mucous secretion and autotomy of the caudal region are methods by which the animal may protect itself against the increases of internal concentrations of toxic compounds. In addition, 50 to $70 \%$ of the administered dose of toxicants was recovered within 24 days of administration [8]. These protection mechanisms appear to be effective, since they led to decontamination of the worms [25].

\section{Conclusions}

This study documents the adverse effects of formaldehyde and pyridine on the chlorophyll, protein and biomass of L. minor and mortality, growth, protein and glycogen content of T. tubifex. T. tubifex can defend themselves from toxic effects of pyridine and formaldehyde by continuous mucous removal and autotomy of the caudal region. Whereas, in absence of well-defined defense system in aquatic plants, formaldehyde and pyridine easily cross the cell membrane and exert a phytotoxic action, especially on the photosynthetic apparatus. So, L. minor was found a sensitive test model than T. tubifex and can be used as a reliable indicator model for assessment of whole effluent (WET) as well as compounds toxicity. While applicability of the results is limited by the scope and design of the experiments, they shed light on an area in which little research has been done and improve our understanding of the effect of pyridine and formaldehyde in freshwater ecosystems.

Acknowledgements. We thank the Director, Industrial Toxicology Research Centre, Lucknow for his encouragement and the financial assistance from Department of Biotechnology, New Delhi is highly acknowledged.

\section{REFERENCES}

[1] Ammon, J.C. (1985): Worms toxicity tests using Tubifex tubifex (Müller) (oligochaeta, tubifidae) and seven other tubificid species. - Archives of Hydrobiology 139: 92-100.

[2] APHA-AWWA-WEF (1998): American Public Health Association, American Water Works Association and Water Environmental Federation: Standard methods for the examination of water and wastewater. 18th ed, Washington, DC.

[3] Behra, R., Genoni, G.P., Joseph, A.L. (1999): Effects of atrazine on growth, photosynthesis and between-strain variability in Scenedesmus subspicatus (Chlorophyceae). - Archives of Environmental Contamination and Toxicology 37: 36-41.

[4] Black, O.A. (1965): Methods in Soil Analysis-II. USA: American Society of Agronomy.

[5] Bradford, M.M. (1976): A rapid and sensitive method for the quantitation of microgram quantities of protein utilizing the principle of protein-dye binding. - Annal of Biochemistry 72: 248-254.

[6] Browning, E. (1965): Pyridine. - In: Toxicity and metabolism of industrial solvents. Amsterdam: Elsevier. pp. 304-309.

[7] Budavari, S., O’Nei,l M.J., Smith, A., Heckelman, P.E., Obenchain, J.R., Gallipeau, J.A.R., D'Arecca, M.A.. (2001): The Merks Index. 13ed., NJ: Merck \& Co, Inc.

[8] Caldwell, J., D'Souza, J., Smith, R.L. (1980): Species variations in the N-methylation and quaternization of $\left({ }^{14} \mathrm{C}\right)$-pyridine in vivo. - British Journal of Pharmacology 68: 119-125.

[9] Carrol, N.V., Longlev, W.W., Roe, H.J. (1956): Glycogen determination in liver and muscle by use of antron. - Biological Chemistry 220: 583-590. 
[10] Casal, J.A., Vermaat, J.E., Wiegman, F. (2000): A test of two methods for plant protein determination using duckweed. - Aquatic Botany 67: 61-67.

[11] Chandra, R., Singh, B.B. (2005): $\mathrm{pH}$ dependent toxicity of pyridine raffinate to common duckweed, Lemna minor L. - Bulletin of Environmental Contamination and Toxicology 74: 886-893.

[12] Chapman, P.M. (2001): Utility and relevance of aquatic oligochaetes in ecological risk assessment. - Hydrobiologia 463: 149-169.

[13] Clément, B., Cadier, C. (1998): Development of a new laboratory freshwater/sediment microcosm test: First results. - Ecotoxicology 7: 279-290.

[14] Creeth, J.M. (1978): Constituents of mucus and their separation. - British Medical Bulletin 34: 17-23.

[15] Dizer, H., Wittekind, E., Fischer, B., Hensen. P.D. (2002): The cytotoxic and gnotoxic potential of surface water and wastewater effluent as determined by bioluminescence, umu -assays and selected biomarkers. - Chemosphere 46: 225-233.

[16] Fliegmann, J., Sandermann, H. (1997): Maize glutathione-dependent formaldehyde dehydrogenase cDNA: A novel plant gene of detoxification. - Plant Molecular Biology 34: 843-854.

[17] Francois, D.L., Robinson, G.G.C. (1990): Indices of triazine toxicity in Chlamydonomas geitleri. - Aquatic Toxicology 16: 205-228.

[18] French, D., Edsall, J.T. (1945): The reactions of formaldehyde with amino acids and proteins. - Advances in Protein Chemistry 2: 277-283.

[19] Giese, M., Bauer-Doranth, U., Langebartels, C., Sandermann, H. (1994): Detoxification of formaldehyde by spider plant (Chlorophytum comosum L.) and soybean (Glycine max L.) cell suspension. - Plant Physiology 104:1301-1309.

[20] Goeddertz, J.G., Weber, A.S., Ying, W.C. (1990): Startup and startup of an anaerobic biological activated carbon (AnBAC) process for treatment of a high strength multicomponent inhibitory wastewater. - Environmental Progress 9: 110-117.

[21] Higashio, Y., Shoji, T. (2004): Heterocyclic compounds such as pyrrole, pyridines, pyrrolidine, piperidine, indole, imidazol and pyrazines. - Applied Catalyst 260: 251-259.

[22] Kemp, A., Heijningen, A.J.M.K.V. (1954): A colorimetric method for the determination of glycogen in tissues. - Journal of Biochemistry 56: 646-648.

[23] Kihara, Y., Kasuya, M., Tanaka, K. (1962): Reaction of aldehydes on starch. - I Dempun Kogyo Gakkaishi 101-9.

[24] Kruglov, Y.V.E.I.P. (1970): Detoxification of simazine by microscope algae. Mikrobiologiya 39: 157-160.

[25] Lucan-Bouche, M.L., Biagianti-Risbourg, S., Arsac, F., Vernet, G. (1999): An original decontamination process developed by the aquatic oligochaeta Tubifex tubifex exposed to copper and lead. - Aquati Toxicology 45: 9-17.

[26] Martin, N.A. (1986): Toxicity of pesticides to Allolobophora caliginosa (Oligochaeta: Lumbricidae). - New Zealand Journal of Agricultural Research 29: 699-706.

[27] Mayer, P., Cuhel, R., Nyholm, N. (1997): A simple in vitro fluorescence method for biomass measurements in algal growth inhibition testes. - Water Research 31: 25252531.

[28] Mayer, P., Jensen, J.F. (1995): Factors affecting results of algal toxicity tests. MS Thesis. Institute for Environmental Science and Technology. Lyneby: Technical University of Denmark.

[29] Mohan, S.V., Sistla, S., Guri, R.K., Prasad, K.K., Kumar, C.S., Ramakrishna, S.V., Sarma, P.N. (2003): Microbial degradation of pyridine using Pseudomonas sp. and isolation of plasmid responsible for degradation. - Waste Management 23: 167-171.

[30] Mosleh, Y.Y., Paris-Palacios, S., Couderchet, M., Biagianti-Risbourg, S., Vernet, G. (2005): Metallothionein induction, antioxidative responses, glycogen and growth changes in Tubifex tubifex (Oligochaete) exposed to the fungicide, fenhexamid. - Environmental Pollution 135: 73-82. 
[31] Mukherjee, S., Mukherjee, S., Bhattacharyya, P., Duttagupta, A.K. (2004): Heavy metals levels and esterase variations between metal-exposed and unexposed duckweed Lemna minor: Field and laboratory studies. - Environment International 30: 811-814.

[32] Nash, T. (1953): The colorimetric estimation of formaldehyde by means of the Hantzsch reaction. - Biochemical Journal 55: 416-421.

[33] OECD (2002): OECD guidelines for testing of chemicals: Lemna sp. growth inhibition test. Organisation for Economic Corporation and Development, Berlin. 22 pp.

[34] Pessala, P., Schultz, E., Nakari, T., Joutti, A., Herve, S. (2004): Evaluation of wastewater effluents by small-scale biotests and a fractionation procedure. - Ecotoxicology and Environmental Safety 59: 263-272.

[35] Phipps, G.L., Ankley, G.T., Benoit, D.A., Mattson, V.R. (1993): Use of the aquatic oligochaeta Lumbriculus variegates for assessing the toxicity and bioaccumulation of sediment-associated contaminants. - Environmental Toxicology and Chemistry 12: 269279.

[36] Reddy, K., Locke, M.A. (1996): Molecular properties as descriptors of octanol-water partition coefficients of herbicides. - Water Air and Soil Pollution 86: 389-405.

[37] Ribeiro, S., Sousa, J.P., Noguerira, A.J.A., Soares, A.M.V.M. (2001): Effect of endosulfan and parathion on energy reserves and physiological parameters of the terrestrial isopod Porcellio dilatatus. - Ecotoxicology and Environmental Safety 49: 131138.

[38] Saravana Bhavan, P., Geraldine, P. (2000): Aberration in various parameters of bioenergetic in in the Macrobrachium malcolmsonii following exposure to endosulfan. Aquaculture 1: 141-150.

[39] Sharma, S., Ramakrishna, C., Desai, J.D., Bhatt, N.M. (1994): Anaerobic biodegradation of a petrochemical waste-water using biomass support particles. - Applied Microbiology and Biotechnology 40: 768-771.

[40] SRC (1995): Syracuse Research Corporation. Octanol-water partition coefficient program (KOWWWIN, Version 1.37, Serial L0148). Chemical Hazard Assessment Division, Syracuse, NY: Environmental Chemistry Centre.

[41] Starr, T.B. (1983): Mechanisms of formaldehyde toxicity and risk evaluation. In: Clary, J.J., Gibson, J.E., Waritz, R.S. (eds.): Formaldehyde- Toxicology, epidemiology and mechanisms. New York: Marcel Dekker, pp. 237-258.

[42] Swenberg, J.A., Kerns, W.D., Mitchell, R.L., Gralla, E.J., Pakov, K.L. (1980): Introduction of squamous cell carcinomas of the rat nasal cavity by inhalation exposure to formaldehyde vapor. - Cancer Reserch 40: 3398-3402.

[43] Tong, Z., Hongjum, J. (1997): Use of duckweed (Lemna minor L.) growth inhibition test to evaluate the toxicity of acrylonitrile, sulphocyanic sodium and acetonitrile in China. Environmental Pollution 98: 143-147.

[44] Verschueren, K. (1983): Handbook of environmental data on organic chemicals. 2nd ed. New York, NY: Van Nostrand Reinhold Company. 